\title{
Universitas Padjadjaran concern for sustainable water resource from West Java to national and to the world
}

\author{
Cipta Endyana ${ }^{1,2,3}$, Teguh Husodo ${ }^{1,2}$, Hendarmawan ${ }^{1,2,3}$, Tri Hanggono Achmad ${ }^{1}$ \\ ${ }^{1}$ Universitas Pdjadjaran, Kampus Jatinangor, Sumedang 45363, Indonesia \\ ${ }^{2}$ Postgraduate School of Universitas Padjadjaran, Kampus Bandung, Bandung 40132, Indonesia \\ ${ }^{3}$ Faculty of Geology Universitas Padjadjaran, Kampus Jatinangor, Sumedang 45363, Indonesia
}

\begin{abstract}
The implementation of Sustainable Development Goals (SDGs) which have been set according to the Peraturan Presiden No. 59 tahun 2017 about The Implementation of SDGs to achieve the purpose of SDGs in Indonesia. Through the implementation of universal, integrated, and inclusive principles of 2030 Agenda for SDGs, a new dawn of development that changes the direction of itself, that enveloping human rights and equality in social, economy, and environment, could be accomplished. UNPAD understand, as a seat of learning and to give real contribution, both in the community and national development, by adopting transformative education paradigm, which seek more activities in university level for better community through the idea of sustainability and sustainable development, and its written as Principle Scientific Pattern of Universitas Padjadjaran: bina mulia hukum dan lingkungan hidup dalam pembangunan nasional. Our research was started to perform through multi and transdiscipline-based with all stakeholder involved such as local government, industry side and community. The study areas were focused on most West Java and Banten where region related with industry. Researches were divided into 4 stages, start from study until monitoring stage. As appreciation, Universitas Padjadjaran reached Indonesia Green Award (2013, 2014) and Green World Awards (2017). What's Unpad researcher has done is a step in engagement to ensure the availability and management of sustainable water and sanitation in accordance once of SDGs in the environmental sector life.
\end{abstract}

\section{Introduction}

In the context of global, the strengthening focus of university role on the sustainable development agenda is in line with the global agreement of Sustainable Development Goals (SDGs), which is an Agenda aiming for better world by 2030 through 17 aims and 169 targets. In line with the agreement of SDGs, on the university level, there is a Higher Education Sustainability Initiative platform to support SDGs. This platform is adopted by 272 Universities from 47 countries, and for Universitas Padjadjaran its imprinted on the Pola Ilmiah Pokok (PIP) or Principal Scientific Pattern: "bina mulia hukum dan lingkungan hidup dalam pembangunan nasional" (building a noble development of law and environment in national development). The attempt of fulfilling SDGs' goals by Universitas Padjadjaran, is started by looking at the needs of Cities and Districts within West Java through the program of "Unpad Nyaah ka Jabar", which is expected to have a national wide impact and becoming a regional effort as "from West Java to the world through sustainable development".

"Bina mulia hukum dan lingkungan hidup dalam pembangunan nasional" is the cornerstones of a lofty philosophy, that will always have remembered and implemented during the implementation of tridharma in UNPAD. Based on this idea, the role and attention of
Universitas Padjadjaran on environmental field, is being formed into study program that specifically studied environmental issues since late 1990s and changed Pascasarjana Program into School of Pascasarjana by 2015 , which focused on the environmental sustainable issues, both in education and research, and encouraging the accomplishment of Sustainable Development Goals (SDGs) through inter- and trans-discipline approach. Strengthen existing SDGs study centers and establishing new study center which relates to the efforts of achieving SDGs by Mei 2016. With an approach that is also interand trans- disciplinary, those study centers expected to be sharpen UNPAD's role on the accomplishment of sustainable development goals, in addition to the roles that have been done by academic community of UNPAD, directly or indirectly.

PIP that had formulated to fulfilling the vision of Universitas Padjadjaran, is implemented on the tridharma UNPAD. Among them, then formed into a study program that specifically studied environmental issues since late 1990s and changed Pascasarjana Program into School of Pascasarjana by 2015, which focused on the environmental sustainable issues, both in education and research, and encouraging the accomplishment of Sustainable Development Goals (SDGs) through inter- and trans-discipline approach. Strengthen existing SDGs study centers and establishing new study center which relates to the efforts of achieving

* Corresponding author: cipta.endyana@,unpad.ac.id 
SDGs through Mei 2016, and on February 2018, a center for inter- and trans- disciplinary research on the environment and sustainability science was inaugurated.

The UNPAD's strategic program of Rencana Induk Riset (RIR) inserted into the implementation of leading research that determined rationally by paying attention to the human resources, available facilities, and critical and strategic issues, whether its local, regional, national, or worldwide. The leading research of UNPAD are planned as a semi top down and determined based on the research goals written in RIR UNPAD 2012-2016. Leading research is set by paying attention to the competence, advantages, and research roadmap of each faculty; national, regional, and university research policy; and also, the strategic and critical national, regional, and worldwide problems/issues. All of the UNPAD's leading research are an interdisciplinary-oriented to give a real contribution to help solving the problem exist in regional/national/West Java or even world wide. UNPAD's leading research could be in form of a basic research, applied and action research that oriented to the economic independence, competitiveness, and poverty reduction for better community. During 2012-2016, UNPAD has 5 fields of leading research: 1. Food, 2. Environment, 3. Health, 4. Energy, 5. Policy, Culture, and Information.

\section{Research in Universitas Padjadjaran: overview}

Based on the RIR Universitas Padjadjaran 2016-2016 which implemented in the implementation of tridharma on 5 research fields [17], Eco Campus cluster through water resources field focused, raised the importance of UNPAD to conduct management and conservation of water resources. In the concept of Hydrology, ground water is one of the components within the hydro cycle that highly related to the underground water availability, precipitation, infiltration, percolation, evapotranspiration, and surface run-off. Conceptually, the condition of water recharge and discharge area, could be identify by studying the water spring spread available. For this matter, the knowledge of condition of potential water catchment area and the ground water behavior is highly important, particularly from the water recharge area to the discharge area.

As resources, water is a essential resource for human being, animals, and plants. Therefore, it is substantial of knowing and understanding water sources, its characteristic, also the good management and utilization. Jatinangor and Sumedang are one of the example of volcanic area that have good potention of water resources. Its landscape that varies from valley to hills, is an area well suited for the availability of recharge area and discharge zone of ground water. However, the geological characteristic of volcanic deposits which always change in short period of time and complex geological structure, quite influential on the ground water flow system in the area. The outlet of ground water to surface could be caused by the intersection of ground water level as the result of the contact of permeable rocks with the impermeable, and the present of a fault.

Universitas Padjadjaran is an education institution with a large number of academic community, reaching up more than 30,000 people, requires vast area of land and also a large quantity of ground water. Ground water scarcity will occur if the management done by UNPAD is not suitable with the aqifer system characteristic and the existing ground water system on the area. Therefore, UNPAD understand that there is a importance of conducting research about the characteristic of groundwater and aquifer system existing within the area as a consideration to determine an integrated work program in term of conserving ground water. The research strategy used, is based on the research roadmap on environmental field, so the main achievement of environmental friendly campus could be fulfilled. Fulfilling the condition of environmental friendly campus consist of several stages of eco-building, ecoplace, eco-behavior, eco-relationship, and eco-services. (Fig. 1) [17].

To ensure the suitableness of this water resources research as a leading environmental research includes: 1) Framing the ground water conservation master plan as a guidance of recommendation in campus construction and infrastructure development based on the ground water conservation. 2) Determine a critical priority zone of ground water use from the upstream (water catchment and recharge area), managing the available potential within the campus and its conservation, and increase the capability if water recharge area within campus for downstream. 3) Socialization and education as a form of delivering research result and masterplan to the stakeholders, in order to supporting the recommended working programs. 4) Implemented the working programs based on the recommendation of masterplan study for groundwater conservation within designated location and timeframe. 


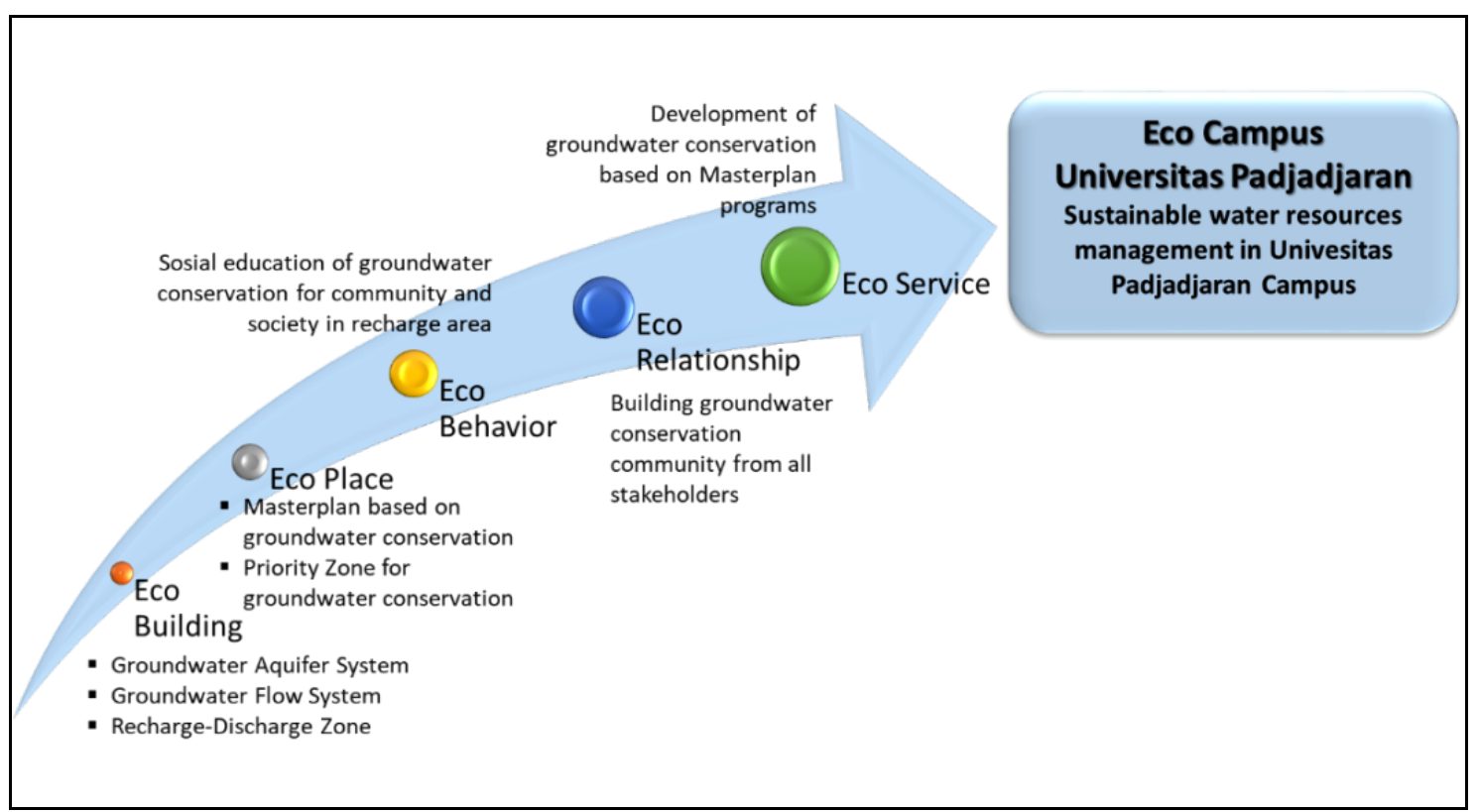

Fig. 1. Leading research on environmental of Universitas Padjadjaran.

\section{Integrated and Collaboration in Environmental Research}

Universitas Padjadjaran, on its research development of Environmental field, is trying to contribute the research result for the whole community, particularly people of West Java. Integrated research model is developed by Universitas Padjadjaran as Research University in its participation on development, have an up-to-date research design and could give a correlated, efficient, and effective solution for the environmental issues for both government and industrial, as the stakeholder on development.

The needs of government and industrial for mentoring by the university is indispensable, where both sector requires research to resolve up rising problems caused by development process and for the practical solution as a best practice based on the theory from the university. Cooperation and collaboration, up till today on the level of West Java Province, among others is being conducted on Kabupaten Bogor, Sukabumi, Cianjur, and Sumedang. While on national level, the collaboration is being conducted on some places in Sumatra, Borneo, and Sulawesi. Research collaboration with industrial sector until today is done with regard to exploring ground water resource and monitoring the quantity and quality of ground water, among others is collaborating with private company (PT. Danone, PT. Biofarma, PT. Chevron), and others company.

Integrated Research Design Collaboration developed, is not only being focused on the government and industrial sector only, but it is also developed for the community that merging as environmental care community. The university has Tri Dharma Perguruan Tinggi which consists of Education, Research, and Community Services. Therefore, in addition to research and education, Universitas Padjadjaran has the responsibility to increase community Capacity Building in informal knowledge. On its relation to environmental management, in line with improvement of the community quality that grouped into environmental communities, they can participate and have an active role on the development as supervisors and volunteers in the handling of environment. 


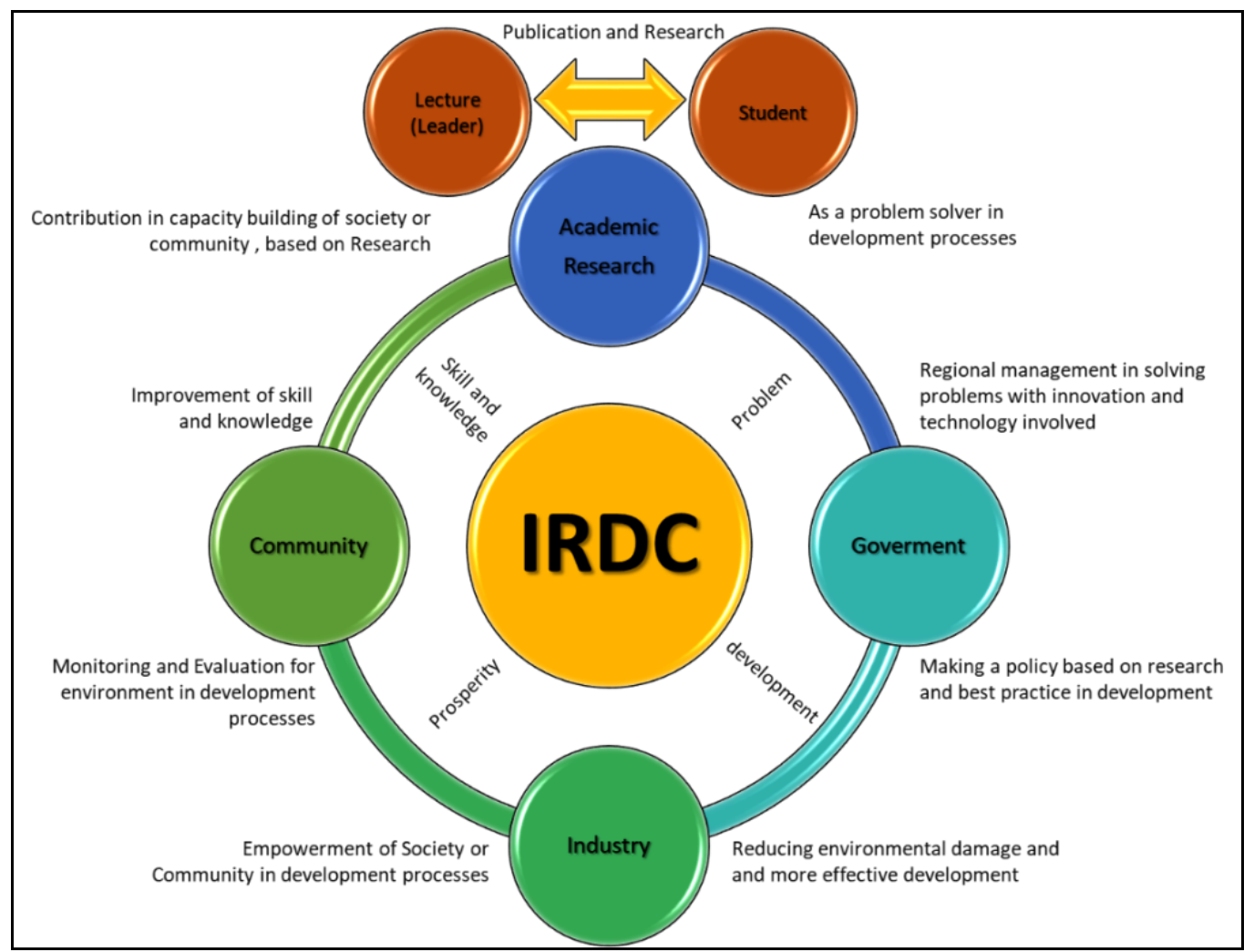

Fig. 2. Integrated research design collaboration

\section{Sustainability water resources management}

According to the hydrology cycle concept, not all infiltration water (ground water) flows into river or other water reservoirs, but there are some infiltration water remains in the top soil to be evaporated back in to the atmosphere through soil evaporation and transpiration. The evaporated water comes from soil through the mechanism of plant physiology, so the evaporation is called transpiration. In other word, intersection occurs during and immediately after the rain. While the transpiration process takes place when there is no rain. Based on the short description above, it is known that ground water conservation research is a continuous research, requires a long implementation stages from framing steps, planning integrated master plans and implementing. Some of the steps framed until today are:

\subsection{Aquifer characteristic studies stage}

Research on this early period is a basic research to understand and determine surface and undersurface lithology. The research was conducted for three years. In the same time, ground water research on site was also being conducted to ensure source and ground water slow, water movement duration, and measuring its infiltration and run off ratio $[15,16]$. Further updates on this research mention that a ground water isotope study is being conducted by Environmental Team of Universitas Padjadjaran for a year in a vast area (Hendarmawan, 2014) [1,2,3].
In short, the result of this early research is a direction of ground water conservation strategies that could be done in short amount of period with an artificial model [4], such pond, infiltration-well, and bio pore. And also, in addition to considering technical factors, supporting non-technical factor is also worth mentions as a recommendation, such as social involvement of the community for the soil conservation [5]. The result also indicates a recommendation for an infiltration zone or area that requires being well-managed $[6,7]$, like the infiltration and preservation program of Desa Sindangsari and Desa Cileunyi Wetan. And for the water movement duration, this research indicated that two drilled-well on UNPAD showing that the groundwater in it has a lifespan in range of 1090-2120 years before now (Before Present). And for the research result regarding upstream and downstream, the area of UNPAD indicates as a infiltration area or zone of shallow ground water of downstream [13], and this result encourages UNPAD to restoring the ground water immediately through artificial infiltration like bio pore, infiltration well and injection well $[8,14]$.

\subsection{Planning and implementing stage}

Research on the conservation planning is a follow through research and this stage was conducted for 2 years. Combining the result data of ground water basin study, land use data, demography, recharge and watershed map using spatial analysis, statistical and couple of water balance simulation scenario. As for the result of the master plan of groundwater conservation 
research, priority ground water conservation zone was determined, based in three main indicators: hydrology, agriculture, and social-economy $[9,10,11]$. The direction of recommendation generated among other are: implementing concept of eco building, developing water pond and injection well $[12,13]$. On this stage, some recommendations is already being implemented, such as 1) making of bio pore on a specific site like the Faculty of Nursery, Medical School, Faculty of Dentistry, and at the south part of campus, 2) completing the injection well near Rectorate building and Medical School building with the minimum depth of 75 meter, and 3) involving people in building water pond and infiltration well in Desa Sindangsari Kecamatan Sukasari Jatinangor.

\subsection{Monitoring stage}

Monitoring stage is aiming to keep the quantity of ground water within the campus of UNPAD Jatinangor available for 4 years. This stage is already being implemented, however not all area of the campus is represented. The important result from this stage is the implementation of the solution for the ground water conservation is no longer requires researcher on data collection, but ground water conservation communities which comes from the local community and local government, while the researcher of Universitas Padjadjaran would acting as supervisors.

In short, Universitas Padjadjaran's step on conducting the management of water resources is shown in this roadmap below (Fig. 3)

\begin{tabular}{|c|c|c|c|}
\hline Study Stage & Planning Stage & Implementation Stage & Monitoring Stage \\
\hline $\begin{array}{l}\text { During } 2 \text { years for study activity } \\
\text { - Groundwater Aquifer System } \\
\text { Study } \\
\text { - Groundwater Flow System } \\
\text { - Gtudy } \\
\text { - Groundwater Isotope Study }\end{array}$ & $\begin{array}{l}\text { During 1-2 years for planning } \\
\text { activity } \\
\text { - Masterplan study based on } \\
\text { groundwater conservation } \\
\text { - Determining Priority Zone of } \\
\text { groundwater conservation }\end{array}$ & $\begin{array}{l}\text { During } 2 \text { years for Implementation activity } \\
\text { - Development of supporting groundwater } \\
\text { conservation infrastructures (Biopores, } \\
\text { waterpond, and artfifical drainage) } \\
\text { - Injection Well } \\
\text { - Sosial education of groundwater } \\
\text { conservation for community and society in } \\
\text { recharge area }\end{array}$ & $\begin{array}{l}\text { During 3-4 years for } \\
\text { Monitoring activity } \\
\text { - } \quad \text { Rain gauge } \\
\text { - } \quad \text { Flow Indicator } \\
\text { - Observation Well }\end{array}$ \\
\hline
\end{tabular}

Fig. 3. Roadmap of water resources conservation management system.

\section{Achievement}

The integrated research conducted in span of 10 years by Universitas Padjadjaran has giving an active role in the environmental competition, both on national and international scale. And for it, the achievement acquires are:

- Indonesia Green Award 2013

- Indonesia Green Campus Award 2014

- Green World Award 2017, an award from Green Organization which offers Universitas Padjadjaran as the Ambassador for Green Organization on Education and Best Practice Sector for environment to worldwide.

\section{Closing}

Sustainability water resources management research is one of the effort of Universitas Padjadjaran to improve the quality of Life on the campus environment and nearby community based on the Sustainable Development Goals (SDGs) [18], particularly the SDGs target of (6.4): significantly improving the efficiency of water use in all sector, and ensuring the sustainability of utilization and availableness of freshwater to counter water scarcity; (6.5) implementing integrated water resource management in all level including on point cross sector cooperation; (6.6) protecting and restoring ecosystem relates to the water resources, particularly on mountains, forest, wet lands, river, ground water, and lakes; and (6.7) supporting and strengthened local people participation in improving water management.

Acknowledgement. This Research of Sustainable Water Resources is conducted with the long terms period and systematic stages. The collaboration between academic, government, industries, and communities become important to make this reseacrh accomplished. This research has been supported by many researchers at Universitas Padjadjaran, Ministry of Research, Technology and Education of Indonesia, Ministry of Environmental and Forestry of Indonesia, Government of West Java Province and its belowed Sumedang, Sukabumi, Cianjur, Bogor, Bandung District, and several industries contrubution those are PT. Danone, PT. Bioframa, PT. Chevron, and others.

\section{References}

1. Clark, I., Fritz, P., Environmental Isotopes in Hydrogeology, Lewis Publisher (1997)

2. Payne, B., and Y. Yutsever, "Environmental Isotopes as a Hydrological Tool in Nicaragua", Isotope Technique in Groundwater Hydrogeology $\mathbf{I}$ (1974)

3. IAEA - Vienna, Stable Isotope Hydrology, Deuterium and Oxygen-18 in the WaterCycle.

4. Domenico, P.A. and Schwartz, W.F., Physical and Chemical Hydrogeology. John Wiley and Sons, Inc., Canada, 824p (1990)

5. Brooks, K.N., P.F.F. Folliott, R. Touchan, Sustaining the Benefits of Integrated Watershed Management and Coping with Climatic Variability. Paper for discussion, CIFANS, University of Minnesota, USA (2010) 
6. Chiras, Daniel D., Environmental Science, $8^{\text {th }}$ Edition, Sudbury, Massachusetts: Jones and Bartlett Publisher (2009)

7. Chao-Hsien Liaw and Yao-Lung Tsai, Optimum Storage Volume of Rooftop Rain Water Harvesting System for Domestic Use, Journal of the American Water Resources Association; 2004; 40, 4; Proquest Agriculture Journals pg. 901 (2004)

8. Sharpe, William E. and Swistock, Bryan., Household Water Conservation, College of Agricultural Sciences, Agricultural Research and Cooperative Extension College of Agricultural Sciences, The Pennsylvania State University (2008)

9. Thomas, Terry, Rainwater Harvesting: Practical Action, School of Engineering, University of Warwick, Coventry CV4 7AL, UK (tanpa tahun)

10. To'th, J., A theoretical analysis of groundwater flow in small drainage basin. Journal of Geophysics Research, 68: 4795-4812 (1963)

11. Worm, Janette \& Hattum, Tim van., Rainwater Harvesting For Domestic Use, Agrodok 43, Agromisa Foundation and CTA, Wageningen

12. Mau, D.P., Winter, T.C., Estimating ground-water recharge from streamflow hydrographs for a small mountain watershed in a humid climate, New Hampshire, USA. Ground Water, 35: 291-304 (1997)
13. To'th, J., A theoretical analysis of groundwater flow in small drainage basin. Journal of Geophysics Research, 68: 4795-4812 (1963)

14. Fetter, Jr. C.W., Applied hydrogeology. Bell and Howell Company, Colombus, Ohio, 488p (1980)

15. Freeze R.A., Cherry, J.A., Groundwater. PrenticeHall, Englewood Cliffs, NJ, 604p (1979)

16. Hooper, R.P., Christophersen, N., Peters, N.E., Modeling of Streamwater Chemistry as A Mixture of Soilwater End membersan Application To The Panola Mountain Catchment, Georgia, USA. Journal of Hydrology, 116: 321-343 (1990).

17. Universitas Padjajaran, Rencana Strategis 20152019, Available online at http://www.unpad.ac.id/wpcontent/uploads/2012/07/Renstra-Unpad-20152019.pdf (2015)

18. Kementerian PPN/Bappenas, Available online at $\underline{\text { http://sdgs.bappenas.go.id/ }}$ 